\title{
Evaluation on Role of Electronic Word of Mouth (EWOM) Ads in Customers' Emotions and Choices in E-Shops
}

\author{
Alireza Miremadi \\ Former Assistant professor and Dean of the Department of Management and Economics \\ Sharif University of Technology International Campus, Iran \\ Member of AMA \& CMA \\ Advisory Council of Marketing Practitioners (ACMP) - Canada \\ E-mail: alireza.miremadi@gmail.com \\ Javad Kenarroudi \\ MBA Graduated, Graduate School of Management \\ University of Tehran, Iran \\ E-mail: javadkenarroudi@ut.ac.ir \\ Omidreza Ghanadiof \\ Graduated of Industrial Management, School of Technology \\ University of Central Missouri, USA \\ E-mail: omidof90@gmail.com
}

Received: June 2, 2020

Accepted: June 18, 2021

Published: June 20, 2021

doi:10.5296/ijim.v6i1.18561

URL: https://doi.org/10.5296/ijim.v6i1.18561

\begin{abstract}
The subject titled evaluation on role of Electronic Word of Mouth (EWOM) in feelings and behavior of customers in E-shops was expressed in Digi-Kala Company. Then, research hypotheses and objectives were proposed and methodology, statistical population and needed sample of analysis technique were introduced to achieve goals and results of hypotheses. The
\end{abstract}




\section{Macrothink

findings suggest significant positive effect of (EWOM) on attitude of consumers and their positive emotions. Similarly, social positive and normal emotions may also have significant impact on attitude of consumers. At the same time, negative emotions of consumers have positively affected consumers' attitudes as well. Finally social norms and attitudes of consumer may have significant positive effect on behavior of consumers.

Keywords: Electronic Word of Mouth (EWOM), Consumer behavior, Social media, Satisfaction 


\section{Introduction}

As one of the foremost and oldest informal communication tools, Electronic Word of Mouth (EWOM) advertisements play an efficient role in marketing processes e.g. encouragement of individual to buy the products and using services. Many consumers mainly rely on EWOM they have obtained from their friends and relatives because such information is more reliable than commercial ads and remarks of marketers (Davari et al., 2015). Thus, EWOM ads may serve as a path to achieve competitive advantages within an environment where trusting in promotional organizations and advertises has been reduced. Having impact on ideas of other individuals may be followed with noticeable benefits for goods and services supplier companies (Jalilvand \& Ibrahimi, 2011). EWOM refers to interpersonal communication between consumers regarding their assessments and experiences of a certain enterprise or product (Jason et al., 2010). The studies have shown that EWOM might act more effective than communication by other sources e.g. recommendations of important contents in newspapers or advertisements (Jalilvand \& Samiei, 2012).

Marketing by EWOM is more credible than other marketing techniques since only fourteen percent of those persons who watch, read or hear commercial ads may trust in them. More interestingly, ninety percent of individuals trust in their families, friends or colleagues if they confirm a certain product or service because they know there is no benefit in approving for them (Jalilian et al., 2012).

\section{Necessity of Research}

EWOM is the communications about goods and services between individuals that seem not to be dependent on goods or service producer enterprise. Such communications may be bilateral dialogues that are done face-to-face or via phone, email, cellular or other communicational canals (Forati et al., 2014). Independency of EWOM from the company is one of the factors that empower EWOM. Another factor that seems to be more important that the first one is that EWOM conveys experiences of the individuals and provides indirect experiences for individuals about the product or service (Hassangholipour et al., 2013). EWOM may be in positive (praising of trade name and product) and or negative (gossip about trade name and product) form. Both types of such communications are spread very quickly and they may play major role in customer's attitude about newly introduced product in the market or the products with riskability in their purchase (Martensen \& Mouritsen, 2014).

\section{Research Objectives}

The present research takes step by aiming to determine effect of EWOM on emotions and attitudes of customers and to specify their impact on behavior of consumers.

Analysis on relationship between EWOM and positive emotions in consumers

Analysis on relationship between EWOM and negative emotions in consumers

$>$ Review on relationship between positive feelings of consumers and their attitude

$>$ Review on relationship between negative feelings of consumers and their attitude 
Analysis on relationship among social norm and positive emotions of consumers

$>$ Analysis on relationship among social norm and negative emotions of consumers

Determination of relationship among social norm and attitude of consumers

$>$ Determination of relationship among social norm and behavior of consumers

$>$ Analysis on relationship among attitude of consumers and their behavior

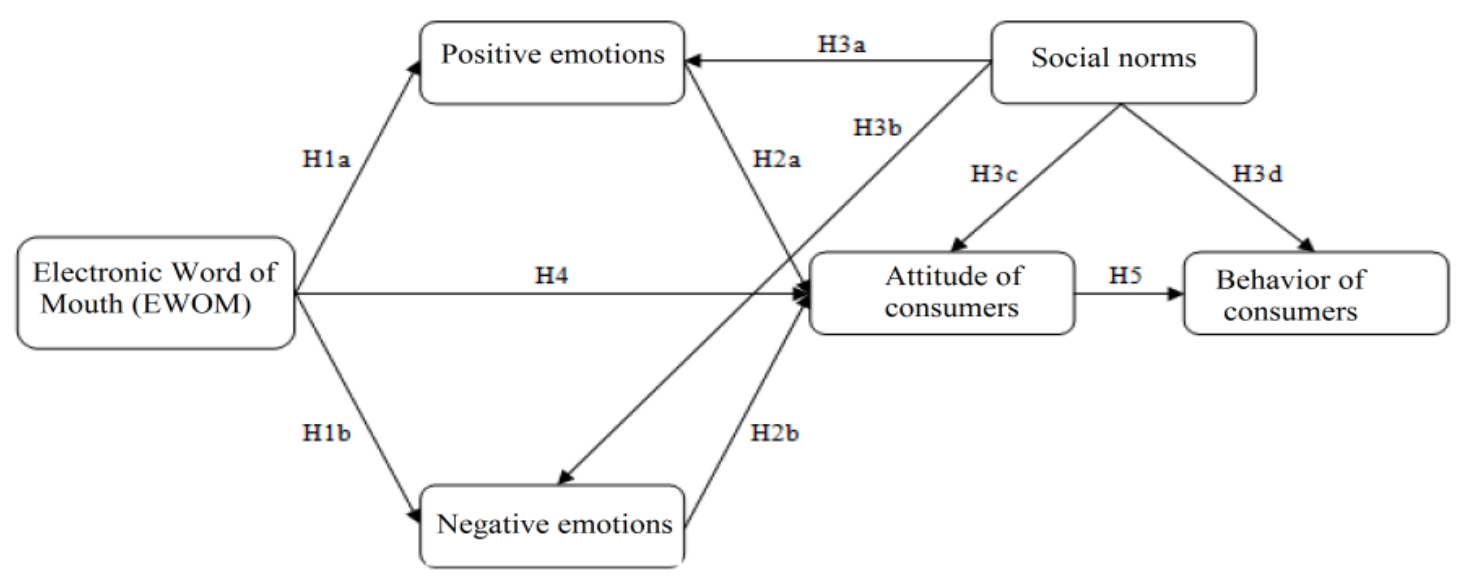

Figure 1. Research conceptual model excerpted from Martensen \& Granhault (2016)

Electronic Word of Mouth (EWOM) advertisements: EWOM is a novel forum where the consumers are shared in their experiences and assessments about various brands and products via online communication canals (Pikas \& Sorrentino, 2014). EWOM is defined as all informal communications between consumers by internet-based technology relating to application or features of certain goods or services and or their vendors (Stephen \& Ronald, 2008). In order to evaluate this variable and by exploitation from paper of Martensen \& Granhault (2016), 6 questions have been considered using Likert 5-scale spectrum.

Emotions: Emotions are the first part of a logical decision caused by neural communications that is conveyed from emotional unit of brain to rational part of it (Martensen \& Granhault, 2016).

$>$ Positive emotions: The positive emotions are created relating to buying a product when this purchase is favorable for the individual. Using paper from Martensen and Granhault (2016) in this study, 6 questions have been considered to assess this variable by Likert 5 -scale spectrum.

$>$ Negative emotions: Negative emotions emerge regarding purchase of a product if buying of the given product is unpleasant to the individual. In this study, 6 questions have been considered to assess this variable by Likert 5 -scale spectrum by means of paper from Martensen and Granhault (2016).

Social norms: In terminology of sociology science, norm denotes a behavioral pattern that 
regulates relations of social reactions (Yousefi et al., 2012). To assess this factor in this survey, 2 questions have been designated by Likert 5-scale spectrum using paper from Martensen and Granhault (2016).

Attitude of consumer: Attitude expresses internal emotions that reflect someone's favorable or unfavorable idea about certain subjects (Chakravarty et al., 2010). Attitude of customer has been addressed as a factor which determines form and direction for his/ her behavior to buy a certain commodity (Chu \& Kim, 2011). In order to evaluate this variable in this investigation, 4 questions have been considered using Likert 5-scale spectrum and by means of paper from Martensen and Granhault (2016).

Behavior of consumers: Behavior of consumers denotes tendency of consumer to buy a specific products and or receive a certain service in the future (Wu et al., 2011). Using Likert 5 -scale spectrum in this study, 3 questions were designated by using paper from Martensen and Granhault (2016).

\section{Difference between E-business and E-commerce}

E-business denotes a group of business-related activities such as marketing, financial subjects, buying and sale, customers' relationship, after sale services and cooperation with investors etc. via internet network while E-commerce only comprises of buying and sale related subjects via internet and it is assumed as a subordinate for internet business system perse. Overall, many benefits and advantages can be considered for E-business. The E-business cut the hands of dealers and brokers and at the same time causes reducing advertisement costs, increases marketing opportunity, improves knowledge about market and strategic planning and finally develops range of participation by customers in giving the services in new system. Accordingly, both producers and consumers will be benefitted from this system.

As one of the subsets of ICT groups, E-business has experienced high growth in the past decade so that the approach taken in this policy is efficient and effective in most of commercial institute in acceptance and employing E-business to enter world markets and to attract new customers and in this regard. Although using E-business in commercial activities needs to a series of influential exogenous and endogenous factor so that if commercial enterprises pay attention to these factors and planning for favorable utilization from technology of E-business may prepare the ground for growth of user enterprises rather than a guarantee for successful exploitation from this process (Movahedi, 2015).

\section{Internet Ads Dimensions}

Internet advertisements include various dimensions which are briefly mentioned in the followings (Gao et al., 2002). Dimensions of internet ads are shown in Figure (1-2). 


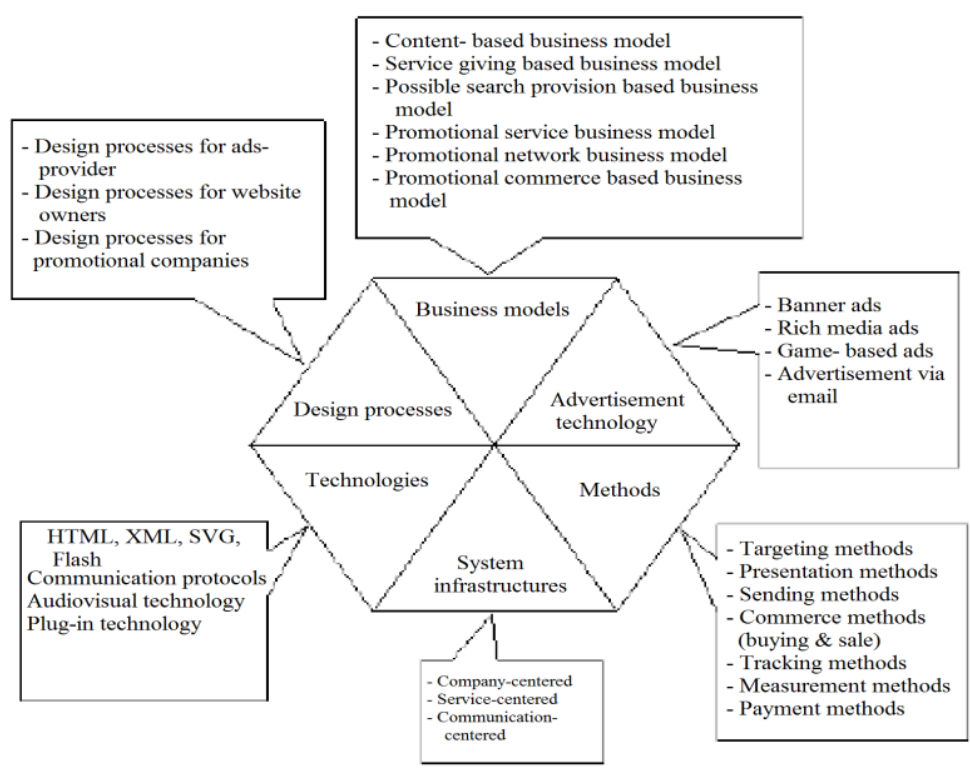

Figure 2. Various Dimensions of Internet Ads (Gao et al., 2002).

Table 1. Comparison of different forms of internet promotions (Gao et al., 2002, p. 18)

\begin{tabular}{|c|c|c|c|c|}
\hline \multicolumn{2}{|c|}{ Game- based ads } & Commercial letter & Rich-media banners & Banners \\
\hline Ads as game & $\begin{array}{c}\text { Sending letter } \\
\text { together- } \\
\text { messages- } \\
\text { newsletter- news } \\
\text { groups }\end{array}$ & Rich-media banner & $\begin{array}{l}\text {-Fixed banners- } \\
\text { Animated banners- } \\
\text { interactive banners }\end{array}$ & $\begin{array}{l}\text { Form of ads } \\
\text { presentation }\end{array}$ \\
\hline $\begin{array}{l}\text { Payment based on } \\
\text { ads presentation- } \\
\text { click based } \\
\text { payment }\end{array}$ & $\begin{array}{c}\text { Pay as you see- } \\
\text { payment based } \\
\text { on number of } \\
\text { letter }\end{array}$ & Click- based payment & $\begin{array}{c}\text { Click- based } \\
\text { payment- pay as you } \\
\text { see }\end{array}$ & Payment method \\
\hline Variable & Very low & High & Low & $\begin{array}{l}\text { Ads design and } \\
\text { sending costs }\end{array}$ \\
\hline $\begin{array}{l}\text { Goods marketing } \\
\text { and sale- creating } \\
\text { trade name }\end{array}$ & $\begin{array}{l}\text { Goods } \\
\text { promotion }\end{array}$ & $\begin{array}{l}\text { Goods and sale } \\
\text { marketing- creating } \\
\text { trade name }\end{array}$ & $\begin{array}{l}\text { Goods and sale } \\
\text { marketing- creating } \\
\text { trade name }\end{array}$ & Advertisement uses \\
\hline Variable & Low & High & Low & Downloading speed \\
\hline $\begin{array}{l}\text { Game related } \\
\text { technologies }\end{array}$ & Internet letters & $\begin{array}{l}\text { Rich0media technology } \\
\text { e.g. Flash,SVG, } \\
\text { IntrVU,RealAudio, } \\
\text { RealVideo }\end{array}$ & $\begin{array}{c}\text { JavaScript and } \\
\text { JavaApplet, and } \\
\text { Animated GIF }\end{array}$ & Used technology \\
\hline $\begin{array}{l}\text { Limited to ones } \\
\text { play }\end{array}$ & $\begin{array}{l}\text { Ones with email } \\
\text { addresses }\end{array}$ & $\begin{array}{c}\text { Limited to users that } \\
\text { have access to that page }\end{array}$ & $\begin{array}{l}\text { Limited to users that } \\
\text { have access to ads } \\
\text { page }\end{array}$ & $\begin{array}{l}\text { Advertisement } \\
\text { audiences }\end{array}$ \\
\hline $\begin{array}{c}\text { Low rate } \\
\text { visibility- high } \\
\text { rate click }\end{array}$ & $\begin{array}{l}\text { Low rate } \\
\text { visibility- low } \\
\text { rate click }\end{array}$ & $\begin{array}{l}\text { High rate visibility- } \\
\text { High rate click }\end{array}$ & $\begin{array}{l}\text { High rate visibility- } \\
\text { low rate click }\end{array}$ & Performance \\
\hline Low & High & Very high & Low & $\begin{array}{l}\text { Attractive for } \\
\text { observer }\end{array}$ \\
\hline
\end{tabular}




\section{Electronic Word of Mouth (EWOM) ads}

EWOM marketing is done in various forms including buzz marketing (using news and amusement), viral marketing (publishing messages especially via email), and community marketing (Creation and supporting from some communities such as followership associations and clubs and user groups), product seeding (to put suitable product at disposal of influential subjects at right time), influencer marketing (to find influential individuals and communities) and brand- blogging (creation and participation in weblog through valuable information (Goyette et al., 2010).

Table 2. Typology of EWOM communication canals (Radmehr et al., 2011)

\begin{tabular}{|l|l|l|}
\hline \multicolumn{1}{|c|}{ Type of canal } & \multicolumn{1}{|c|}{$\begin{array}{c}\text { Interaction } \\
\text { level }\end{array}$} & \multicolumn{1}{c|}{ Communication domain } \\
\hline Electronic letters (emails) & Asynchronous & One by one \& one by multiple \\
\hline Instant messages & Synchronous & One by one \\
\hline $\begin{array}{l}\text { Websites, visiting product and other } \\
\text { websites }\end{array}$ & Asynchronous & $\begin{array}{l}\text { One by multiple \& multiple by } \\
\text { multiple }\end{array}$ \\
\hline Thinking rooms & Synchronous & One by multiple \\
\hline Weblogs and virtual communities & Asynchronous & One by multiple \\
\hline News groups e.g. Google news group & Synchronous & One by multiple \& multiple by one \\
\hline
\end{tabular}

\section{Domestic Literature Review}

- In a study titled 'Analysis of effects of EWOM marketing on buying intention' Fallah (2017) has implied that EWOM is a novel forum in which consumers are shared in their experiences and assessments of different brands and products e.g. via laptop through online communication canals. In today world, an ordinary person may be exposed to a mass of marketing messages which are produced by traditional marketing methods such as commercial and promotional ads and consumer is destined to select among a mass of promotional offers. EWOM marketing includes informal communications about a certain product or services that could be utilized as a valid filter for the users because independence and lack of reliance of EWOM on producers may draw consumer's trust. Alternately, controlling EWOM marketing by enterprises can create a competitive advantage in today market. The current research has been conducted in order to analyze effect of EWOM marketing on decision for purchase.

- In their investigation under title of 'Interpretation of tendency of customers to use BMI banks of services in Guilan Province focusing on EWOM promotion', Roohbakhsh and Fadaei (2017) have declared that entry of IT into various industries has exerted a lot of changes in their different processes. Banking industry is one of the foremost industries which 
have been subject to many changes by entry of IT. In this sense, the main objective of aforesaid study was to interpret tendency of customers to use BMI banks of services in Guilan Province focusing on EWOM promotion. This study is applied type based on objective and it is a type of descriptive researches in terms of data collection. The research statistical population was customers of Melli Bank (BMI) in Guilan Province. Given the studied population is unlimited thus Cochran's formula for unlimited population was employed for selection of sample. The sampling technique that has been used for this study is of clustered and non-probabilistic available sampling type. The data collection method was used in this survey was field study and questionnaire was utilized as tool for data collection. The content validity has been used for measurement of validity rate and also Cronbach alpha coefficient was employed to measure reliability for which reliability rate was derived higher than 0.7 for all variables in this model. All of collected data were analyzed by SPSS and PLS software. Confirmatory factor analysis was utilized to test research hypotheses and structured equation modeling was adapted by taking ordinary least square (OLS) approach. The result of research hypotheses suggested approval for all hypotheses in this study.

- In a study under title of 'EWOM and its impacts on customer's intention for purchase', Nasiri Sarvi and Haffari (2017) have mentioned that after Industrial Revolution and automation of products and thus rising rate of supply, factory owners concluded that they should introduce and promote for their commodities if they intended to be able to sell their goods and after a short period of time marketing science was founded. Today, modern marketing techniques have been introduced to the world and they are more efficient, cheaper and effective than old methods out of which one can refer to types of one-by-one marketing, phone marketing, remote marketing, partisan marketing, viral marketing and word of mouth marketing etc. The librarian method has been utilized in aforesaid study. It has been tried in aforementioned study to introduce generally EWOM marketing, methods of use and the given effect on intention to purchase in customers.

- In an investigation with the title of 'EWOM advertisements and its impact on behavior of consumer', Beigi and Ibrahimi (2015) have implied that in today excessively competitive markets, directors of enterprises look for new techniques to inform the people about their products and to improve their trade names. They adapt various marketing techniques to attract more customers to achieve their goal. One of the most effective types of these methods that have formed according to relationship between individuals is Electronic Word of Mouth (EWOM) marketing. Following to rising number of internet users in Iran during recent years, a suitable opportunity has been provided for the enterprises to increase knowledge of customers about their products by benefitting from this modern method along with traditional marketing methods rather than increase in their market share and thereby to improve trade name for the company. In this regard, subject of EWOM marketing has been analyzed by the given reviews and studies in this paper. It has been focused on importance of EWOM marketing in the reviewing studies.

- Khalilzadeh and Asgari Sabzkoohi (2015) have explored relations among EWOM advertisement and making decision to buy Huawei mobile phones. They expressed in this investigation that EWOM advertisements are implemented in line with the same comments 
and positive and negative experiences of consumers versus other consumers or individuals who intended to buy a product such as mobile phone in order to reduce buying risk and to release from confusion in buying among similar products in internet environment. This survey aims to review relations among EWOM ads and decision for buying Huawei mobile phone. This study has been an applied- researching research in terms of goal and a survey in terms of data collection method. Questionnaire was utilized as a tool to collect data and data analysis was done using some parameters e.g. mean and standard deviation and level of effect exerted by EWOM advertisement to intention of customers for purchase and related standard deviation have been measured 4.90 (of total 5 score) and 0.56 by means of the results from SPSS software application respectively and these rates indicated positive effect of EWOM advertisement on intention of purchase in consumers of Huawei mobile phones.

- In a study that was conducted by Boroomand and Aberoomandi (2015) with title of 'Analysis of effect of EWOM ads on intention for repurchase by online customers', they mentioned that today extensive competition has been increased within various commercial fields especially E-commerce throughout the world compared to the past and maintenance of customers and rising their loyalty became more difficult and providing for their requirements could contribute to improving loyalty of customers. The main objective designated for this study was to find the foremost factors for continuous use of Digi-Kala website by internet buyers and also effective factors on EWOM ads among customers of Digi-Kala Company that is today assumed as the leader of this market in sale of electronic commodities in the country based on the published statistics. In order to collect data in this study and for analysis on 9 major hypotheses, 385 questionnaire forms were collected after distribution of them among respondents. The results of data analysis were derived using SPSS and LISREL software that indicated approval for all research hypotheses.

- In a study under title of 'Effect of oral advertisements on tendency to use from insurance services among customers of insurance companies in Rasht city', Davari et al. (2015) have expressed that the oral advertisements might play efficient role as one of the paramount and oldest informal tools for communications in marketing processes such as encouragement of persons to buy products and to use services Mireamdi et al. (2013). Many consumers mainly rely on EWOM information they received from their friends and relatives because they considered such information as more reliable than commercial ads and statements by marketers (Ghanadiof, 2017) Therefore, in an environment where the consumer trusts lesser in organizations and their advertisements, the oral ads may provide a way to acquire competitive advantage and enable the commercial organizations and enterprises thereby to affect customers' intention for purchase. With respect to importance of the subject, the present research has tried to analyze effect of oral advertisements on using services between customers of insurance industry. This study is one of descriptive- correlational researchers in terms of method and nature and it is of applied type in terms of objective. The statistical population of current study includes active insurance companies in Rasht city and 300 questionnaire forms were distributed among them to select sample using simple randomized sampling technique. The structured equation modeling has been utilized for data analysis and testing research hypotheses. The findings resulted from this study suggest that dimensions of 
oral advertisements i.e. intensity, positive potential, negative potential, content of oral advertisements as well as image of company may affect tendency of customers to use insurance services.

\section{Foreign Literature Review}

- In a paper titled 'the antecedents of purchase and re-purchase intentions of online auction consumers', Jengchung et al. (2016) implied that they have used two PChome and eBay Auction Sites for data collection. In this paper, 120 veteran customers have participated from both of these sites so that to measure effect of past experiences on intention for repurchase. The results of study have indicated that all designated variables were confirmed by the researchers and effect of perceived trust and risk has been expressed by the customers at different level. These findings have clearly specified complexity of decision-making process in online auctions. Likewise, this investigation has indicated that there was the attitude of interest and enjoyment among buyers and sellers in online purchase process.

- In a study under title of 'a research on effectiveness of Facebook advertising on enhancing purchase intention of consumers', Dehghani and Tumer (2015) explored effect of FaceBook as a social network on rising purchase between consumers in 2013. The findings signified that FaceBook ads might remarkably affect image and special value of the brand and both of these variables might contribute to noticeable change in intention for purchase in consumers.

- In their survey under title of 'effective marketing communication via social networking site: The moderating role of the social tie', Shen et al. (2015) expressed the FaceBook has provided a path for communication with online friends that could increase effect of internet ads. In this investigation, researchers have utilized conceptual framework based on social capital and theory of communications including dependence intensity, type of message and promotional literacy level. The findings resulted from analysis on 346 collected questionnaires have indicated that the interactive promotion might give wider attitude to the consumers about advertisement and sharing of messages compared to non-interactive promotion. The social dependence is an important factor for moderating effects of message type and promotional literacy level on efficient communications (Cheraghi et al., 2012, p. 3)

- In their study titled 'viral effects of social network and media on consumers' purchase intention', Gunawan and Huarng (2015) analyzed importance of viral marketing in social networks. The results showed that social integration has no effect on subjective norms among consumers in social networks. Similarly, their findings indicated that social influence along with perceived risk in social networks might affect purchase intention in consumers.

- In a study, Hudson et al. (2015) explored effects of social media on emotions, quality of brand relations and EWOM marketing by conducting experimental survey on participants in music festival and concluded that on the one hand, interaction of social media might noticeably affect emotion and at the same time in EWOM marketing and also perceived emotions with quality of brand relations might influence in EWOM marketing that has led to the given findings.

- In a survey, Amonrat (2014) examined impact of social media on EWOM marketing. In 
this investigation in which he has analyzed users of various types of social media, he indicates that EWOM has positive and significant impact on consumers as well as intensity of utilization from social networks by the users. Thus, social media may create efficient tools for attraction of demand for various goods and services and he shows innovative marketing tools enable the enterprises to prepare their own for adaptation to new virtual lifestyle by investment in advanced communication technologies.

\section{Research Conceptual Model}

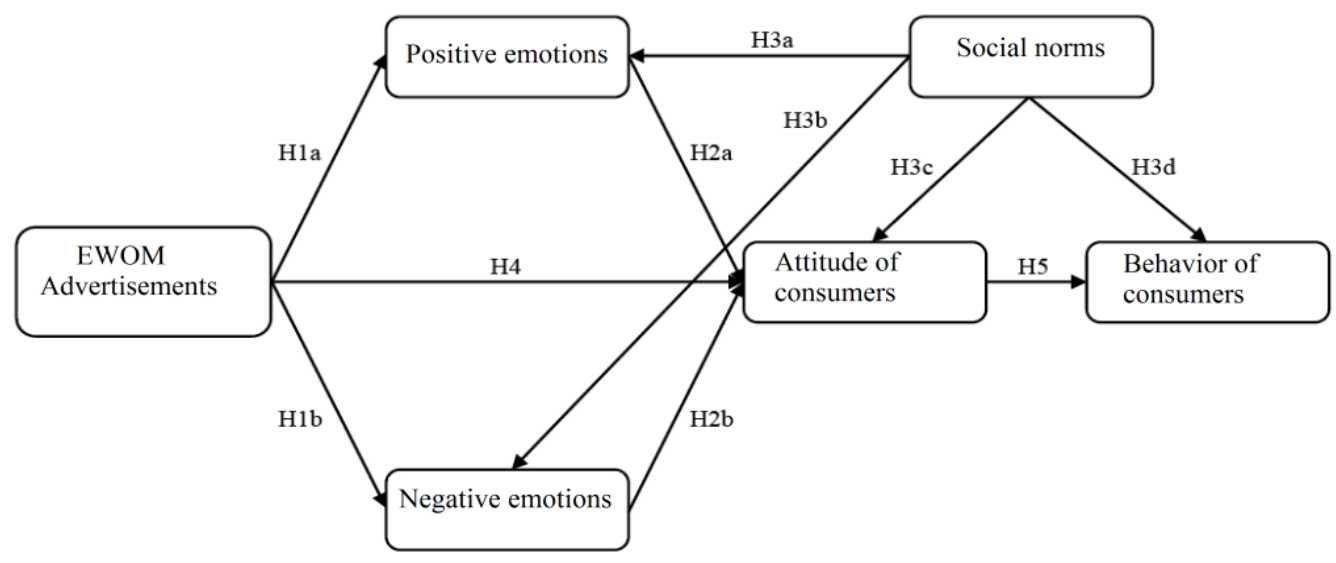

Figure 3. Research conceptual model excerpted from study of Martensen and Granhult (2016)

\section{Research Methodology}

This study is a deceptive- analytical research in terms of type and nature because researcher looks for analysis and description of relationship among behavior of consumers, EWOM, customer's emotions and social norms. Alternately, whereas method and level of effects of variables and their correlation are studied it is typically assumed as a correlational research as well. A statistical population includes a group of individuals or units with one common attribute at least (Fardhosseini et al., 2021, p. 58). The studied population in survey is usually the statistical population for which researcher intends to study about variable attribute (attributes) of the given units (Sarmad et al., 2011). The Simple Random Sampling (SRS) method has been employed for this study. With respect to Cochran's sampling formula and given this rule that statistical population of this study (all customers of Digi-Kala website) is the unlimited number thus the minimum quantity necessary sample size is 384 samples for this investigation. Whereas some of collected questionnaires may probably include heterogeneous and unreliable data and some of respondents may avoid from completion of questionnaire, the questionnaire forms were distributed among 420 respondents among them 395 questionnaires were collected but there were some questionnaires with many heterogeneous and lost data in 395 questionnaire forms but finally 385 proper questionnaire forms were analyzed.

The questionnaire has been utilized for data collection in major part of this study and for measurement of research variables. The given questionnaire was standardized and it has been extracted from paper of Martensen and Granhult (2016). Nonetheless, before their 
measurement in this questionnaire, the measured parameters in this study were subject to judgment by several experts and finally the agreed questionnaire was employed as a tool for data collection. This questionnaire comprises of two sections. The first section is concerned with demographic traits and the second part analyzes research variables and includes 24 questions with Likert five-scale spectrum. The aforesaid questionnaire is visible in Appendix 1. Orders and quantity of questions can be seen in the following table:

Table 3. Number Of questions in questionnaire

\begin{tabular}{|c|c|c|c|}
\hline Variable & Number Of Questions & Order & \multirow{2}{*}{ Source } \\
\hline Social norms & 3 & $1-3$ Qs & \multirow{2}{*}{ Martensen and } \\
Behavior of consumers & 3 & $4-6$ Qs & \multirow{2}{*}{ Granhult (2016) } \\
\hline Attitude of consumers & 4 & $7-10$ Qs & \\
\cline { 1 - 3 } EWOM marketing & 4 & $11-14$ Qs & \\
\cline { 1 - 3 } Positive emotions & 5 & $20-24$ Qs & \\
\hline Negative emotions & 5 &
\end{tabular}

\section{Content Validity}

The comments of experts and relevant masters are used in content validity method. For this purpose, the questionnaire has been initially extracted, translated and designed using similar papers and then put at disposal of several experts and scholars to examine transparency and relevance of questions with the research content.

\section{Combined Reliability}

Since Cronbach alpha coefficient is a traditional criterion for determining reliability of constructs, PLS technique is employed as more modern criterion than alpha coefficient under title of combined reliability. This criterion was introduced by Werts (1974) and it is prior to Cronbach alpha in that the reliability of constructs is not computed absolutely but with respect to correlation between their parameters with each other. If the value of Combined Reliability (CR) becomes higher than 0.7 for any construct (Houshangi et al., 2017) it reflects suitable internal consistency for the measurement models while value of reliability less than 0.6 shows lack of reliability. It necessitates noting this point that CR is assumed as a better criterion than Cronbach alpha in structured equation modeling (Vinzi, 2010). Whereas all parameters are calculated with the same importance for each of constructs in computation of Cronbach alpha, the parameters with higher factorial loadings are more important for CR calculation. This causes CR values of constructs to be more real and accurate criteria than Cronbach alpha (Houshangi et al., 2016). Both criteria of Cronbach alpha and combined reliability have been utilized in this study to ensure from reliability of questionnaire and the given measurement. 


\section{Macrothink}

Table 4. Reliability and average variance extracted from research variable

\begin{tabular}{|c|c|c|c|}
\hline Constructs & Cronbach alpha & $\begin{array}{c}\text { Combined Reliability (CR) } \\
\text { coefficient }\end{array}$ & AVE \\
\hline Attitude of consumer & 0.792952 & 0.864449 & 0.614722 \\
\hline Behavior of consumer & 0.853648 & 0.911000 & 0.773357 \\
\hline EWOM advertisement & 0.829238 & 0.897798 & 0.745445 \\
\hline Negative emotions & 0.907438 & 0.930837 & 0.729466 \\
\hline Positive emotions & 0.802977 & 0.865869 & 0.567828 \\
\hline Social norms & 0.878805 & 0.925237 & 0.804889 \\
\hline
\end{tabular}

\section{Measurement Model Test}

Initially, measurement models of research variables were analyzed. This test includes two main processes and several parameters:

- Reliability test: Test reliability is related to measurement accuracy and stability. Reliability has two different meanings: one meaning of term 'reliability' is the stability and persistence of scores over the time; namely, if a test is administered for a single respondent for several times, the score will be the same in all cases. The second meaning of reliability refers to parity of items and this means how much testing questions are correlated. For this purpose, three parameters are used for analysis of reliability using software application:

* Reliability for each of tangible variables (reliability of referents)

* Combined reliability or Delvin- Goldestain- $\mathrm{p}$

* Cronbach alpha coefficient

Both of Cronbach alpha and CR coefficients have been utilized to verify reliability of variables in this study. If Cronbach alpha and CR coefficient are higher than 0.7 , the variables have reliability at favorable level. As it characterized in Table 5, the values of Cronbach alpha coefficients range from 0.792 to 0.907 . Likewise, values of CR coefficients are between 0.864 and 0.930 that indicates suitable reliability for the constructs.

Table 5. Reliability and average variance extracted from research variable

\begin{tabular}{|c|c|c|c|}
\hline Constructs & Cronbach alpha & $\begin{array}{c}\text { Combined Reliability (CR) } \\
\text { coefficient }\end{array}$ & AVE \\
\hline Attitude of consumer & 0.792952 & 0.864449 & 0.614722 \\
\hline Behavior of consumer & 0.853648 & 0.911000 & 0.773357 \\
\hline EWOM advertisement & 0.829238 & 0.897798 & 0.745445 \\
\hline Negative emotions & 0.907438 & 0.930837 & 0.729466 \\
\hline Positive emotions & 0.802977 & 0.865869 & 0.567828 \\
\hline Social norms & 0.878805 & 0.925237 & 0.804889 \\
\hline
\end{tabular}


In order to determine reliability of referents in partial least square technique, factorial loadings test is employed. The values of referents should be higher than 0.6 in factorial loading test. The coefficients of factorial loadings can be observed for questions of research questionnaire in Figure 5.

As it visible in Figure 5, majority of variables has factorial loadings higher than minimum value 0.6 and only one of referents includes factorial loading less than 0.6 and with respect to Baidu's rule (Note 1) and the given average variance extracted (AVE) $(>0.5)$ this referent can be maintained (It should be noted these factorial loadings can be also seen in Table 6 (transverse loadings).

- Validity test: The validity of variables and referents should be determined to analyze validity of model. Parameter of Average Variance Extracted (AVE) is used for determining validity of variables for which the values higher than 0.5 indicate favorable validity. As you observe in Table 5, AVE values range between 0.567 and 0.804 for constructs in this study so these values are greater than the minimum level which indicates favorable validity of constructs.

Transversal loadings test is utilized to determine validity of referents in which factorial loadings of each of referents should be higher that factorial loadings the given referent for other constructs. The results of this analysis are given in Table 6. The results of this investigation denote high validity of referents because all referents have factorial loadings higher in their constructs than their factorial loadings for the constructs.

Table 6. Transversal loadings for research referents

\begin{tabular}{|c|c|c|c|c|c|c|}
\hline SN & PE & NE & EWOM & CB & CA & \\
\hline 0.312549 & 0.430001 & -0.102541 & 0.390690 & 0.436402 & $\mathbf{0 . 8 0 1 6 0 4}$ & CA 1 \\
\hline 0.209375 & 0.218798 & -0.074881 & 0.248888 & 0.314842 & $\mathbf{0 . 7 5 1 1 4 1}$ & CA 2 \\
\hline 0.346861 & 0.307889 & -0.213530 & 0.340032 & 0.428440 & $\mathbf{0 . 8 0 4 5 7 7}$ & CA 3 \\
\hline 0.296199 & 0.231492 & -0.213972 & 0.349950 & 0.388783 & $\mathbf{0 . 7 7 7 6 6 3}$ & CA 4 \\
\hline 0.500700 & 0.511816 & -0.135112 & 0.622616 & $\mathbf{0 . 8 8 3 2 4 7}$ & 0.412986 & CB 1 \\
\hline 0.538211 & 0.526627 & -0.115886 & 0.522280 & $\mathbf{0 . 8 6 9 0 8 0}$ & 0.469208 & CB 2 \\
\hline 0.575859 & 0.591068 & -0.172249 & 0.649265 & $\mathbf{0 . 8 8 5 8 0 3}$ & 0.453114 & CB 3 \\
\hline 0.563921 & 0.597744 & -0.178211 & $\mathbf{0 . 8 7 4 1 7 8}$ & 0.599200 & 0.332658 & EWOM 1 \\
\hline 0.553269 & 0.535970 & -0.183507 & $\mathbf{0 . 8 5 7 6 5 1}$ & 0.586920 & 0.368346 & EWOM 2 \\
\hline 0.557675 & 0.509405 & -0.215453 & $\mathbf{0 . 8 5 8 2 4 4}$ & 0.574922 & 0.418027 & EWOM 3 \\
\hline-0.218456 & -0.071629 & $\mathbf{0 . 9 0 4 8 7 3}$ & -0.233609 & -0.146845 & -0.199694 & NE 1 \\
\hline-0.212711 & -0.105557 & $\mathbf{0 . 8 3 2 6 8 5}$ & -0.202719 & -0.143531 & -0.109290 & NE 2 \\
\hline-0.162799 & 0.025587 & $\mathbf{0 . 8 2 8 8 3 3}$ & -0.118780 & -0.083857 & -0.130667 & NE 3 \\
\hline-0.238511 & -0.077654 & $\mathbf{0 . 8 8 6 4 0 3}$ & -0.177234 & -0.152276 & -0.179130 & NE 4 \\
\hline-0.208040 & -0.110309 & $\mathbf{0 . 8 1 3 9 4 1}$ & -0.198527 & -0.146750 & -0.202280 & NE 5 \\
\hline 0.361750 & $\mathbf{0 . 5 6 8 8 4 6}$ & -0.082935 & 0.438873 & 0.281273 & 0.194304 & PE 1 \\
\hline 0.397628 & $\mathbf{0 . 7 1 0 9 2 9}$ & -0.135801 & 0.502076 & 0.398087 & 0.283866 & PE 2 \\
\hline
\end{tabular}




\begin{tabular}{|l|l|l|l|l|l|l|}
\hline 0.471472 & $\mathbf{0 . 8 2 0 5 5 7}$ & -0.038659 & 0.496928 & 0.601371 & 0.238141 & PE 3 \\
\hline 0.460792 & $\mathbf{0 . 8 3 9 3 2 6}$ & -0.077460 & 0.498379 & 0.578118 & 0.450821 & PE 4 \\
\hline 0.344177 & $\mathbf{0 . 7 9 5 2 0 6}$ & 0.022268 & 0.446921 & 0.425754 & 0.257885 & PE 5 \\
\hline $\mathbf{0 . 9 0 0 6 3 7}$ & 0.457865 & -0.254960 & 0.607570 & 0.545249 & 0.317340 & SN 1 \\
\hline $\mathbf{0 . 8 9 0 6 9 6}$ & 0.527326 & -0.233247 & 0.588689 & 0.533094 & 0.328107 & SN 2 \\
\hline $\mathbf{0 . 9 0 0 1 0 1}$ & 0.481921 & -0.176578 & 0.545224 & 0.573463 & 0.373528 & SN 3 \\
\hline
\end{tabular}

\section{Structured model quality test and assessment}

There are three main criteria for testing structured models in analysis of structured models by the aid of partial least square approach: 1) AVE parameter $\left(\mathrm{R}^{2}\right) ; \mathrm{Q}^{2}$ index; and Goodness of Fit (GOF) as overall fitness.

\section{$\checkmark \quad \mathbf{R}^{2}$ criterion}

Average Variance Extracted is the main criterion for evaluation of endogenous hidden variables of path in model. This index indicates how many percent of variance of endogenous variable is exerted by exogenous variable. Values of $0.67,0.33$ and 0.19 have been described respectively as noticeable, medium and low for the endogenous hidden variables (dependent) in structured path model (internal), but if endogenous hidden variable is affected by some of (one or two) exogenous variables, the lower values of AVE could be accepted as well (Mohsenin \& Esfidani, 2014). The results of this test are visible in Table 8.

\section{$\checkmark \mathbf{Q}^{2}$ criterion}

$\mathrm{Q}^{2}$ criterion is calculated only for endogenous constructs of the model in which indices are of reflexive type and if this value sets zero or less than zero for an endogenous construct, it indicates the relationships have not been well defined between other constructs of the model and the given endogenous construct and consequently, the model needs to correction. Henseler et al. (2009) have determined three values $(0.02,0.15$ and 0.35$)$ for intensity of potential of prediction in endogenous constructs of the model in which these values indicate the prediction potential at low, medium and high levels in a construct versus indices of the given construct. The following table shows $\mathrm{Q}^{2}$ values for each of endogenous variables in the model.

Table 7. $\mathrm{Q}^{2}$ values

\begin{tabular}{|c|c|}
\hline Variable & $\mathrm{Q}^{2}$ criterion \\
\hline Attitude of consumer & 0.134729 \\
\hline Behavior of consumer & 0.341898 \\
\hline Negative emotions & 0.044159 \\
\hline Positive emotions & 0.238684 \\
\hline
\end{tabular}




\section{$\checkmark$ Analysis on Goodness of Fit (GOF) of section}

Unlike (CB-SEM) covariance-based method, there is no index for general measurement of the model in structured equation modeling but an index, called Goodness of Fit (GOF) was offered by Tenenhaus et al. (2005) for this purpose. This index considers both measurement and structured models and is used as a criterion for measurement of general performance of the model. This index ranges within limit between zero and one. Weltz et al. (2009) introduced three values of $0.01,0.25$ and 0.36 respectively as low, medium and high quantities for GOF.

Table 8. GOF

\begin{tabular}{|c|c|c|c|}
\hline Variable & Commonality & R-Square & GOF \\
\hline Attitude of consumer & 0.614722 & 0.228964 & \\
\hline Behavior of consumer & 0.773357 & 0.464965 & \multirow{2}{*}{$\mathbf{0 . 4 5 8}$} \\
\hline EWOM advertisement & 0.745445 & - & \\
\hline Negative emotions & 0.729466 & 0.067659 & \\
\hline Positive emotions & 0.567828 & 0.434306 & \\
\hline Social norms & 0.804889 & - & \\
\hline Mean & $\mathbf{0 . 7 0 5}$ & $\mathbf{0 . 2 9 8}$ & \\
\hline
\end{tabular}

With respect to three values i.e. $0.01,0.25$ and 0.36 that have been introduced as low, medium and high values for GOF (Wetz et al., 2009) 0.458 is verified as high quantity for GOF.

\section{Testing hypotheses}

\section{T-significance coefficient}

Using significant coefficient algorithm in this section we calculate T-statistic. If value of T-statistic is greater than 1.96, it indicates precision of relationship between constructs and as a result confirms research hypotheses at confidence level 95\% (Significance numbers at significance levels $99 \%$ and $99.9 \%$ are 2.58 and 3.27 respectively). The results of this algorithm are shown in Figure 4.

\section{Path coefficients}

PLS algorithm should be used for calculation of standard path coefficients between constructs. The standardized coefficients between independent and dependent variables indicate that the independent variable interprets variance of dependent variable at this percentage. Figure 5 displays standardized coefficients of paths relating to each of hypotheses. 


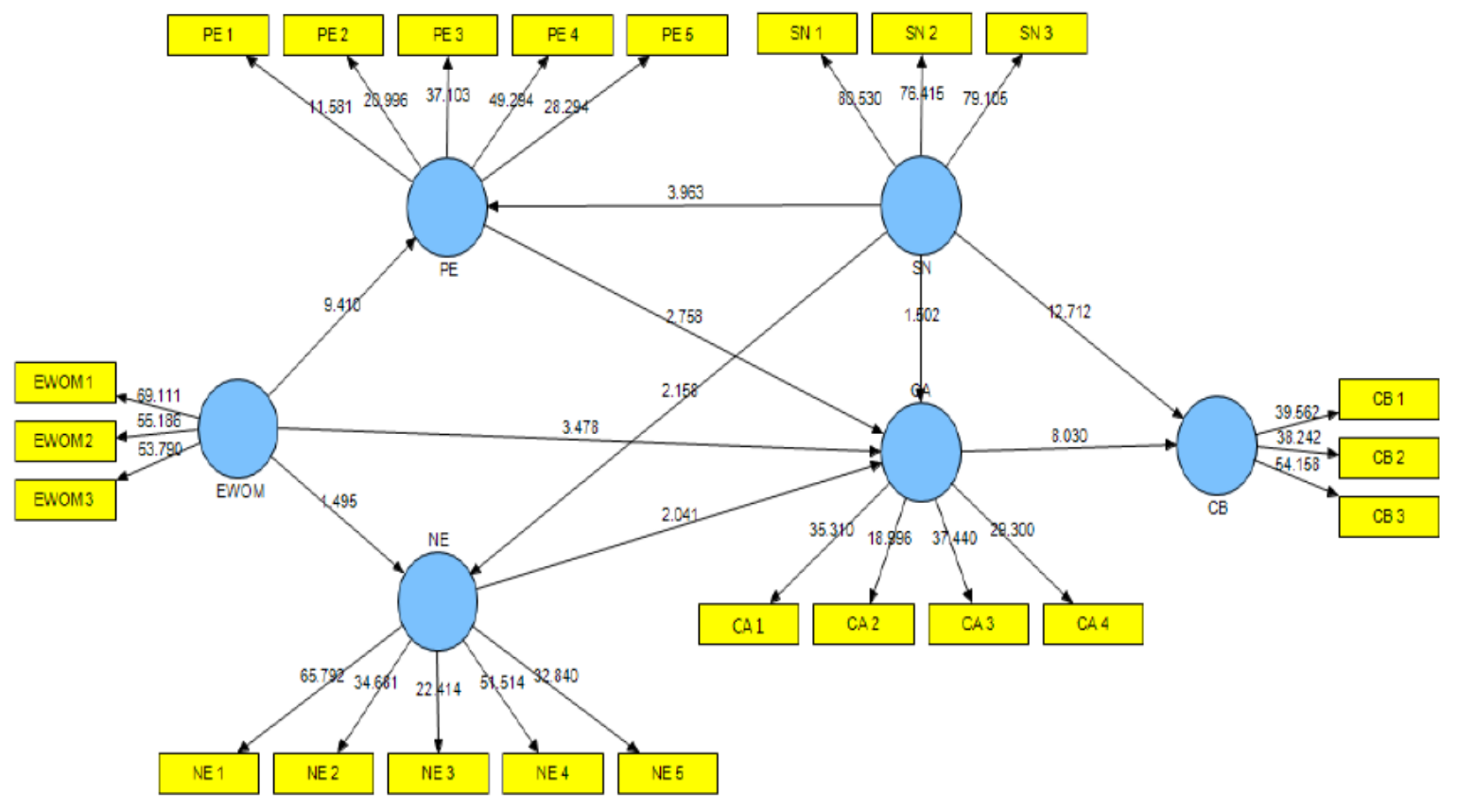

Figure 4. T-statistic between research main variables

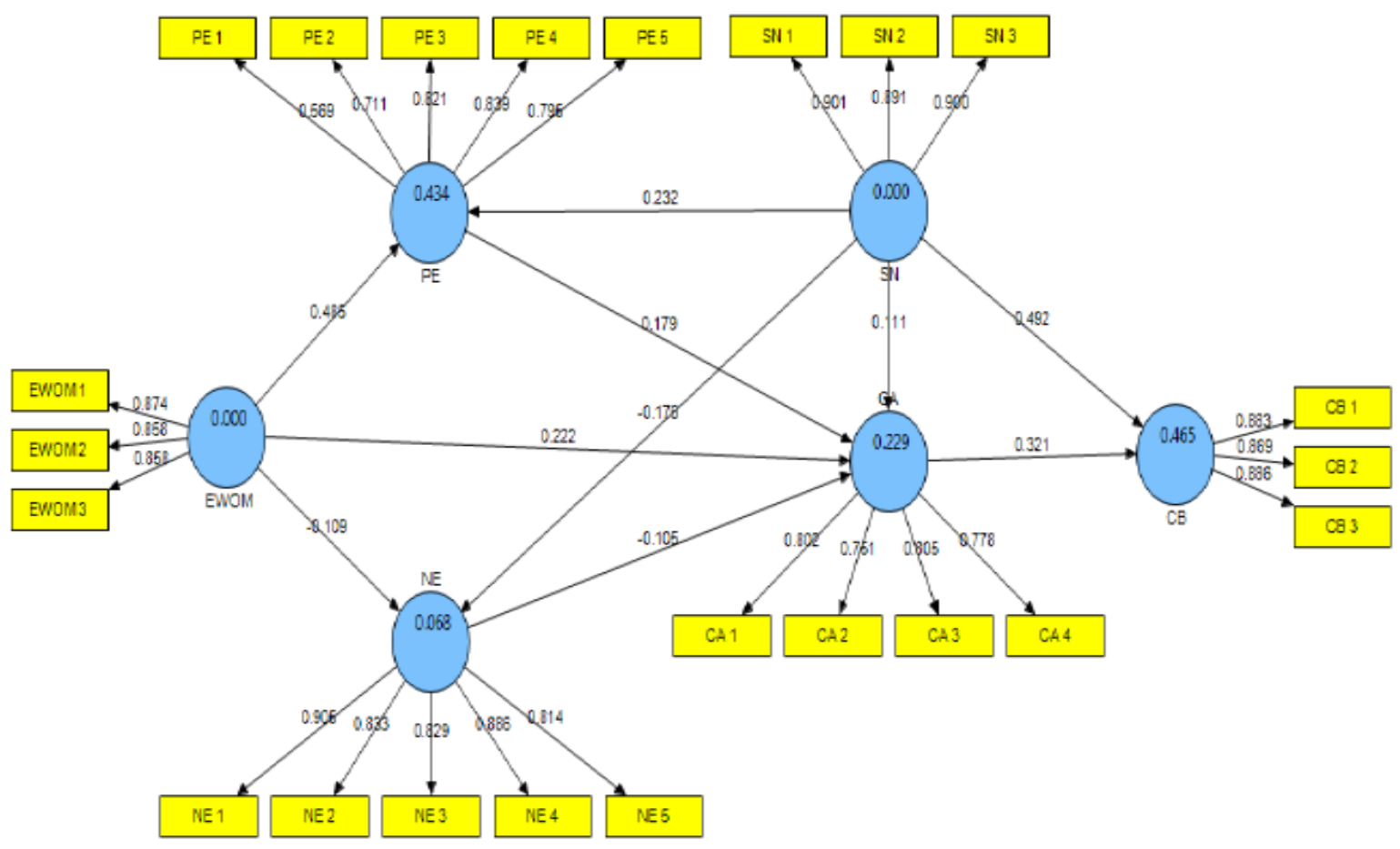

Figure 5. Path coefficients between research main variables

Given the results derived from analysis on the collected data, the results of research hypotheses are generally presented in Table 9. It should be noted that those relations in which value of T-statistic is higher than 1.96 will be confirmed while relations with t-statistic less than 1.96 are rejected. 
Table 9. Approval or rejection of hypotheses

\begin{tabular}{|l|c|c|c|}
\hline \multicolumn{4}{|c|}{ Approval Or Rejection Of Hypotheses } \\
\hline $\begin{array}{l}\text { Research Hypotheses } \\
\text { Coefficient }\end{array}$ & Significance & $\begin{array}{l}\text { Approval/ } \\
\text { Rejection }\end{array}$ \\
\hline $\begin{array}{l}\text { H1a: EWOM advertisement has positive and } \\
\text { significant effect on positive emotions of } \\
\text { consumers. }\end{array}$ & 0.485 & 9.410 & Approved \\
\hline $\begin{array}{l}\text { H1b: EWOM advertisement has reverse and } \\
\text { significant effect on negative emotions of } \\
\text { consumers. }\end{array}$ & -0.109 & 1.495 & Rejected \\
\hline $\begin{array}{l}\text { H2a: EWOM advertisement has positive and } \\
\text { significant effect on attitudes of consumers. }\end{array}$ & 0.179 & 2.758 & Approved \\
\hline $\begin{array}{l}\text { H2b: EWOM advertisement has reverse and } \\
\text { significant effect on negative emotions of } \\
\text { consumers. }\end{array}$ & -0.105 & 2.041 & Approved \\
\hline $\begin{array}{l}\text { H3a: Social norm has positive and significant } \\
\text { effect on positive emotions of consumers. }\end{array}$ & 0.232 & 3.963 & Approved \\
\hline $\begin{array}{l}\text { H3b: Social norm has negative and significant } \\
\text { effect on positive emotions of consumers. }\end{array}$ & -0.178 & 2.158 & Approved \\
\hline $\begin{array}{l}\text { H3c: Social norm has positive and significant } \\
\text { effect on attitudes of consumers. }\end{array}$ & 0.111 & 1.502 & Rejected \\
\hline $\begin{array}{l}\text { H3d: Social norm has positive and significant } \\
\text { effect on behavior of consumers. }\end{array}$ & 0.492 & 12.712 & Approved \\
\hline $\begin{array}{l}\text { H4: EWOM advertisement has positive and } \\
\text { significant effect on attitudes of consumers. }\end{array}$ & 0.222 & 3.478 & Approved \\
\hline $\begin{array}{l}\text { H5: Attitude of consumers has positive and } \\
\text { significant effect on behavior of consumers. }\end{array}$ & $\mathbf{0 . 3 2 1}$ & $\mathbf{8 . 0 3 0}$ & Approved \\
\hline
\end{tabular}

\section{Conclusion and Suggestions}

According to the statistical results derived from statistical analysis in the current research, the relationship was obviously revealed among EWOM advertisement and positive and negative emotions and attitudes of consumers, social norms and behavior of consumers. Therefore, it is obvious that Digi-Kala Company in Tehran city should make effort to enhance EWOM ads, positive and negative emotions, attitudes of consumers, social norms and behavior of the consumers in their organization so that to improve in the performance. Some strategies and solutions are given for improvement of each of influential factors on research variables in the followings.

By focusing on relationship among EWOM advertisement and positive and negative emotions and attitudes of consumers, social norms and behavior of consumers, organizational directors and officials in Digi-Kala Company in Tehran should identify needs and requirements of customers so that their personnel to take step toward improving variables of 
EWOM advertisement and positive and negative emotions and attitudes of consumers, social norms and behavior of consumers. It seems necessary to formulate a suitable operational framework for appropriate planning in order to improve EWOM advertisement and positive and negative emotions and attitudes of consumers, social norms and behavior of consumers. The access to information is facilitated for personnel about EWOM advertisement and positive and negative emotions and attitudes of consumers, social norms and behavior of consumers to improve their relationship with consumers. Thus, codification of training programs and improving conditions for EWOM advertisement and positive and negative emotions and attitudes of consumers, social norms and behavior of consumers based on organizational marketing and promotion and employment of experts in the fields of internet and content generation marketing may be implemented to enable them to enhance EWOM advertisement and positive and negative emotions and attitudes of consumers, social norms and behavior of consumers in the organization.

\subsection{Managerial Implications}

It is discussed about some of uses of research for researchers in this field as well as directors of organizations with respect to the results of hypotheses after review on research hypotheses and findings and comparison of the given results with the previous studies in this regard. Some examples of them are mentioned in the following.

A. Review on different relationships which have been designated in this study will give extensive percept to the readers about quality of effect of these variables on each other especially about way of impact by EWOM advertisement and positive and negative emotions and attitudes of consumers, social norms and behavior of consumers. Given the final objective for many organizations in market is to acquire profit and more market share as well as competitive advantage and eventually improved performance of organization and variables of EWOM advertisement and positive and negative emotions and attitudes of consumers, social norms and behavior of consumers may increase organizational performance so that the results of the current study will help the directors to take step toward improvement of their organizational performance and EWOM advertisement and positive and negative emotions and attitudes of consumers, social norms and behavior of consumers and thereby to acquire competitive advantage versus rivals and satisfaction for the customer.

B. Based on the conducted studies, modern directors should properly perceive effective factors in organizational performance. Findings of this study will lead to better perception in directors of effective factors on their marketing and promotional performance and EWOM advertisement and positive and negative emotions and attitudes of consumers, social norms and behavior of consumers and help them to make better and more comprehensive decisions.

C. With respect to current business environment, directors should look for finding of solutions for improving their organizational performance. Findings of this study indicate directors what variables should be addressed for improving their organizational performance regarding EWOM advertisement and positive and negative emotions and attitudes of consumers, social norms and behavior of consumers. 
D. Given that the rate of influence has been determined for each of variables, by considering the sources at their disposal, directors can allocate the resources for improving performance in EWOM advertisement and positive and negative emotions and attitudes of consumers, social norms and behavior of consumers and avoid from allocation of resources to the subjects with less effect.

E. This is one of the few studies conducted in Iran that has analyzed effect of EWOM advertisement and positive and negative emotions and attitudes of consumers, social norms and behavior of consumers. Therefore, the given results could be assumed as a moderating path and shortcut to be continued in other investigations.

\subsection{Research Limitations}

The presence of many problems and constraints always makes this path difficult and uneven for conducting study. Presence of these limitations certainly has high effect on research trend and the given results with derived interpretations and requires researcher to observe more care and precision in this regard. There were also many limitations in this study some of which will be implied in the followings.

1). Given this study has been carried out within a limited time interval; thus, the effect of research variables on each other has been evaluated in the same time range, but for better assessment of quality of effect of these variables on each other, it would be better to conduct this assessment for several periods and within longer time interval in order to consider further different environmental impacts and conditions. Although lack of additional time for this study and restriction in receiving information caused this objective not to be realized.

2). The limited access to English information references, particularly theses of leading universities in the world and latest information sources caused writing of theoretical literature to encounter some problems. 3.Absence of domestic related studies and investigations with which findings of current study to be compared is one of the limitations to which researcher was exposed.

3). Poor cooperation of statistical population with researcher and lack of adequate care and paying attention to questions in the questionnaire caused some problem in data analysis process.

\subsection{Future Studies}

In the last part of this study, some suggestions are proposed to the interested researchers for conducting studies in the future in this regard so that to clarify path of studies about EWOM advertisement and positive and negative emotions and attitudes of consumers, social norms and behavior of consumers.

It is suggested for considering time period of conducting study for several years thereby to examine better the effect of research variables on each other and to be followed with more stable findings. Surely, researcher could not identify all effective factors on EWOM advertisement and positive and negative emotions and attitudes of consumers, social norms and behavior of consumers and there were some factors which have been overlooked by the 
researcher. Conducting studies about the unidentified factors may be favorable for improvement of organizational performance. At the same time, the effect of more numbers of variables e.g. ease of use can be measured in the forthcoming studies thereby we could achieve a more comprehensive model in this regard. One can test these relations in other organizations and even in other production industries as well to ensure from precision of the derived results.

\section{References}

Abdalvand, M. A., \& Ghaffari, A. P. (2009). Presentation of a model for assessment of effective factors on positive oral advertisements in service market (Case study: Banks in Arak city). Journal of Management Future Inquiry (Management Studies), 81, 35-51.

Arami, A. (2014). Definition of social network. Retrieved from http//:azadeharami.persianblog.ir/post/ 161

Babaei, M. (2011). Hidden power of social networks. Retrieved from http//:www.babaie.ir?/P=301.

Beigi, J., \& Ibrahimi, A. (2015). EWOM and the impact on behavior of consumer. The $5^{\text {th }}$ national conference and the $3^{\text {rd }}$ international conference on accounting and management. Khadamat Bartar Company.

Boroomand, Z., \& Aberoomandi, F. (2015). Review on effect of quality of website on EWOM and purchase intention of online customers. The $4^{\text {th }}$ national conference and the $2^{\text {nd }}$ international conference on accounting and management.

Chakravarty, A., Young, L., \& Mazumdar, T. (2010). The differential effects of online word-of-mouth and critics' reviews on pre-release movie evaluation. Journal of Interactive Marketing, 24(3), 185-197. https://doi.org/10.1016/j.intmar.2010.04.001

Cheraghi, H., Khaligh, A. A., Naderi, A., \& Miremadi, A. (2012). Gaining competitive advantage through marketing strategies in container terminal: A case study on Shahid Rajaee port in Iran. International Business Research, 5(2), 179. https://doi.org/10.5539/ibr.v5n2p179

Christy, M. K., Cheung, M., Lee, K. O., \& Neil, R. (2008). The impact of electronic word-of-mouth: The adoption of online opinions in online customer communities. Internet Research, 18(3), 229-247. https://doi.org/10.1108/10662240810883290

Chu, S. C., \& Kim, Y. (2011). Determinants of consumer engagement in electronic word-of-mouth (eWOM) in social networking sites. International Journal of Advertising, 30(1), 47-75. https://doi.org/10.2501/IJA-30-1-047-075

Davari, A., Mohammadi, A. A., \& Pournaserani, A. (2015). The impact of oral advertisements on tendency to use insurance services among customers of insurance companies in Rasht city. Journal of Marketing Management, 26(10), 115-137.

Dehghani, M., \& Tumer, M. (2015). A research on effectiveness of Facebook advertising on enhancing purchase intention of consumers. Computers in Human Behavior, 49, 597-600. 
https://doi.org/10.1016/j.chb.2015.03.051

Domingos, P. (2005). Mining Social Networks for Viral Marketing. Department of Computer Science and Engineering, University of Washington.

Fallah, Nayer-al-zaman. (2017). Review on impacts of EWOM marketing on purchase intention. The $2^{\text {nd }}$ international conference management and accounting. Tehran: Salehan Higher Education Institute. Retrieved from https://www.civilica.com/Paper-MANAGECONF02 MANAGECONF02_0761.html

Fardhosseini, M. S., Soltaninejad, M., Karji, A., Ghorbani, Z., \& Ghanadiof, O. (2021). Qualitative Evaluation of 5S Application Considering the Experience of Electrical Construction Experts. American Journal of Applied Sciences, 18(1), 51-60. https://doi.org/10.3844/ajassp.2021.51.60

Forati, H., Jokar, A. A., \& Hosseini, B. F. (2014). Proposing a model for evaluation of effective factors on positive oral advertisement in managing urban economic enterprises (Case study: Ansar Bank in Borojerd city). Geographic Journal of Zagros Outlook, 6(19), 143-160.

Gao, J. et al. (2002). Online Advertising: Engineering Perspectives and a Taxonomy.

Ghanadiof, O. (2017). Customer loyalty and powerful brand in heavy machinery industry (Master dissertation, University of Tehran).

Ghanadiof, O. (2021). Customer loyalty and powerful brand in heavy machinery industry. European Journal of Business and Management Research, 6(3). https://doi.org/10.24018/ejbmr.2021.6.3.903

Ghanadiof, O., \& Miremadi, A. (2018). Build your brand in one week.

Ghanadiof, O., Miremadi, A., \& Mohammadian, M. (2021). Strategic Planning and Strategic Analysis of Food Industry Using SWOT. Scientific Research Journals in Management and Social Studies, 2(23), 14-33.

Golshahi, O., \& Tooraj, S. (2014). Analysis of effect of EWOM advertisements on purchase behavior of consumer (Case study: Consumers of tablets and smartphones). International conference on accounting and management. Tehran: Mehr Eshragh Hamayeshgsaran Institute, Center of conferences of University of Tehran.

Goyette, I., Richard, L., Bergeron, J., \& Marticotte, F. (2010). E-WOM scale: Word-of Mouth measurement scale for e-services context. Can. J. Adm. Sci., 27(1), 5-23. https://doi.org/10.1002/cjas.129

Gunawan, D. D., \& Huarng, K. H. (2015). Viral effects of social network and media on consumers' purchase intention. Journal of Business Research, 68(11), 2237-2241. https://doi.org/10.1016/j.jbusres.2015.06.004

Hassangholipour, T., Rahrovi, E., \& Abachian, G. R. (2013). Theoretical and empirical study on predictor factors for oral advertisement of customers about airliner companies (Case study: Iran Air Company). Journal of Business Administration, 5(1), 41-60. 
Henseler, J., Ringle, C. M., \& Sinkovics, R. (2009). The use of partial least squares path modeling in international marketing. Advances in international Marketing, (20). https://doi.org/10.1108/S1474-7979(2009)0000020014

Hooshangi, M., Fazli, S., \& Mirhosseini, S. S. (2016). The mediation role of buyer's satisfaction in relationship between structural capital with performance. Int. J. Logistics Systems and Management, 23(3), 329-342. https://doi.org/10.1504/IJLSM.2016.074715

Iman, K., Niloofar, I. S., \& Fakharian, M. (2013). Analysis of effect of customer-to- customer interactions on satisfaction, loyalty and oral advertisements (Case study: Travelling and tourism agencies in Semnan city). Journal of Researcher (Management), 10(32), 59-78.

Jalilian, H., Ibrahimi, A. H., \& Mahmudian, O. (2012). The impact of EWOM on purchase intention of consumers by special value of customer-based brand among academic students (Case study: Laptop products from Dell Company).

Jalilvand, M. R., \& Ibrahimi, A. (2011). The impact of EWOM communications on purchase of domestic vehicles (Case study: Samand Vehicle- Iran Khodro Inc.). Journal of Business Administration, 3(9), 57-70.

Jalilvand, M., \& Samiei, N. (2012). The Effect of electronic word of mouth on brand image and purchase intention: An empirical study in the automobile industry in Iran. Journal of Marketing Intelligence \& Planning, 30(4), 5-5. https://doi.org/10.1108/02634501211231946

Jason, Q. Z., Georgiana, C., \& Dongwoo, S. (2010). When does electronic word-of-mouth matter? A study of consumer product reviews. Journal of Business Research, 63, 1336-1341. https://doi.org/10.1016/j.jbusres.2009.12.011

Jengchung, V. C., David, C. Y., Wan-Ru, K., \& Erik, P. S. C. (2016). The antecedents of purchase and re-purchase intentions of online auction consumers. Computers in Human Behavior, 54, 186-196. https://doi.org/10.1016/j.chb.2015.07.048

Khalilzadeh, M., \& Asgari, S. L. (2015). Analysis on relations between EWOM advertisements and decision for purchase (Case study: Huawei mobile products). The $2^{\text {nd }}$ international conference of management in $21^{\text {st }}$ century.

Litvin, S. W., Ronald, E., \& Goldsmith, B. P. (2008). Electronic Word-of-Mouth in Hospitality and Tourism Management. Tourism Management. https://doi.org/10.1016/j.tourman.2007.05.011

Lotfi, A. (2015). Review on impact of customer's emotions for repurchase intention with mediatory role of oral advertisements (Case study: Alborz Insurance in Shiraz city). The National Conference of Ocean Management.

Martensen, A., \& Mouritsen, J. (2014). How ad-talk and word-of-mouth influence consumers' responses. Innovative Marketing, 10(2), 58-69.

Miremadi, A., \& Ghanadiof, O. (2021). CRM Competitive Strategy in Financial Institutions. European Journal of Business and Management Research, 6(3), 111-117. 
https://doi.org/10.24018/ejbmr.2021.6.3.867

Miremadi, A., \& Khoei, R. (2013). The art of visual merchandising on consumer buying behavior. International Journal Contemporary Business Studies, 4(6), 34-50.

Movahedi, R. (2015). Setup E-business in agriculture. Journal of Entrepreneurship in Agriculture, (3), 23-42.

Nasiri, S. M., \& Zahra, H. (2017). EWOM advertisements and their effect on customer's purchase intention. The $2^{\text {nd }}$ annual conference on economy, management accounting, Ahwaz University of Shahid Chamran- Khuzestan industry, mines and commerce organization.

Pikas, B., \& Sorrentino, G. (2014). The effectiveness of online advertising: consumer's perceptions of ads on Facebook, Twitter and YouTube. Journal of Applied Business and Economics, 16(4), 70-81.

Prendergast, G., Ko, D., \& Yuen, S. Y. V. (2010). Online word of mouth and consumer purchase intentions. International Journal of Advertising, 29(5), 687-708. https://doi.org/10.2501/S0265048710201427

Radmehr, R., Rezaee, D. H., \& Shalikar, M. (2011). Review on EWOM ads in tourism administration. The $1^{\text {st }}$ international conference on tourism administration and sustainable development.

Rouhbakhsh, M., \& Mehdi, F. (2017). Interpretation of customers' tendency to use BMI banking services in Guilan province with focusing on EWOM advertisements. The $2^{\text {nd }}$ international conference on management of accounting, Tehran: Salehan Higher Education Institute. Retrieved from https://www.civilica.com/Paper-MANAGECONF02-MANAGECONF02_1023.html.

Sarmad, Z., Bazargan, A., \& Hejazi, E. (2011). Methodologies in behavioral sciences. Agah Pub.

Shekari, A., Rahimi, F., \& Kerahi, M. C. (2015). Analysis of effect of relational marketing on purchase decision among customers mediated by oral advertisements. Journal of Marketing Administration, 10(28). 1-14.

Shen, G. C. C., Chiou, J. S., Hsiao, C. H., Wang, C. H., \& Li, H. N. (2015). Effective marketing communication via social networking site: The moderating role of the social tie. Journal of Business Research. https://doi.org/10.1016/j.jbusres.2015.12.040

Stephen, W. L., \& Ronald, E. G. B. (2008). Electronic word-of-mouth in hospitality and tourism management. Journal of Tourism Management, 29, 458-468. https://doi.org/10.1016/j.tourman.2007.05.011

Swamynathan, G., Christo, W., Bryce, B., Kevin, A., \& Ben, Y. Z. (2008). Do Social Networks Improve e-Commerce? A Study on Social Marketplaces. Seattle, Washington, USA. https://doi.org/10.1145/1397735.1397737

Tenenhaus, M., Amato, S., \& Vinzi, V. E. (2004). A global Goodness-of-Fit index for PLS 
structural equation modelling.

Wangenheim, V. F., \& Bayon, T. (2014). The effect of word of mouth on services switching. European Journal of Marketing, 38(9/10), 1173-1185. https://doi.org/10.1108/03090560410548924

Werts, C. E., Linn, R. L., \& Jöreskog, K. G. (1974). Intraclass Reliability Estimates: Testing Structural Assumptions. Journal of Educational and Psychological Measurement, 34(1). https://doi.org/10.1177/001316447403400104

Wetzels, M., Odekerken-Schröder, G., \& van Oppen, C. (2009). Using PLS path modeling for assessing hierarchial construct models: guidelines and impirical illustration. MIS Quarterly, 33. https://doi.org/10.2307/20650284

Wu, P., Yeong, Yeh, G. Y., \& Hsiao, C. (2011). The effect of store image and service quality on brand image and purchase intention for private label brands. Australasian Marketing Journal, 19, 30-39. https://doi.org/10.1016/j.ausmj.2010.11.001

Yousefi, A., Farhoudizadeh, M., \& Lsashkari, D. M. (2012). The pressure of social commitment norm in Iran. Journal Applied Sociology, 23(2), 179-192.

Zhang, J. Q., Georgiana, C., \& Dongwoo, S. (2010). When does electronic word-of-mouth matter? A study of consumer product reviews. Journal of Business Research, 63(12), 1336-1341. https://doi.org/10.1016/j.jbusres.2009.12.011

Zhang, Z., Ye, Q., Law, R., \& Li, Y. (2010). The impact of e-word-of-mouth on the online popularity of restaurants: A comparison of consumer reviews and editor reviews. International Journal of Hospitality Management, 29, 694-70. https://doi.org/10.1016/j.ijhm.2010.02.002

\section{Note}

Note 1. Baidu's rule expresses that if a construct includes a referent with factorial loading less than 0.6 but the given average extracted variance is higher than 0.5 , the referent could be kept. For more information see also the related book, Dr. Adel Azar et al. (2012).

\section{Copyright Disclaimer}

Copyright for this article is retained by the author(s), with first publication rights granted to the journal.

This is an open-access article distributed under the terms and conditions of the Creative Commons Attribution license (http://creativecommons.org/licenses/by/3.0/). 